\title{
MECHANICAL PROPERTIES OF THE GX12CrMoVNbN91 (GP91) CAST STEEL AFTER DIFFERENT HEAT TREATMENTS
}

\author{
G. GOLAŃSKI
}

Institute of Materials Engineering, Czenstochowa University of Technology, Poland

\begin{abstract}
The paper presents results of research on the influence of multistage heat treatment of different types on the microstructure and properties of high-chromium martensitic GX12CrMoVNbN9-1 (GP91) steel. The material under investigation were samples taken out from a test coupon. Heat treatment of GP91 cast steel was performed at the parameters of temperature and time typical of treatment for multi-ton steel casts. The research has proved that in the as-cast state the GP91 cast steel was characterized by a coarse grain microstructure of lath martensite with precipitations of carbides such as: $\mathrm{M}_{23} \mathrm{C}_{6}, \mathrm{M}_{3} \mathrm{C}$ and $\mathrm{NbC}$. The cast steel microstructure in the as-cast state ensured the required standard mechanical properties. Heat treatment of GP91 cast steel contributed to the obtainment of a fine grain microstructure of high tempered lath martensite with numerous precipitations of $\mathrm{M}_{23} \mathrm{C}_{6}$ and $\mathrm{MX}$ carbides of diverse size. The GP91 cast steel structure received by heat treatment made it possible to obtain high plastic properties, mainly impact strength, maintaining strength properties (yield strength (YS)) on the level of the required minimum.
\end{abstract}

Keywords: cast steel, heat treatment, microstructure, properties.

Economical factors and world-wide legal regulations for environmental protection cause reducing of power generating costs and limiting of the contaminants emission into the atmosphere by construction of new power units and modernization of the existing ones. The most efficient way to obtain the abovementioned aims is raising the thermal efficiency level of the power units. Achieving a higher efficiency (to the expected $50 \%$ ) and reduction of the gases emission, mainly $\mathrm{CO}_{2}$ and $\mathrm{NO}_{x}$, into the atmosphere, requires an increase in temperature and steam pressure in many elements of the boilers and turbines. Temperature and pressure of the overheated steam in modern power units increased to the level of $600 \ldots 620^{\circ} \mathrm{C}$ and $30 \ldots 37 \mathrm{MPa}$, respectively (supercritical and ultra supercritical service parameters). Fulfillment of those high requirements entailed the necessity of developing and introducing for usage in the power industry of high-temperature creep resistant steels with higher mechanical properties than the steels used so far. The steels developed and introduced in the power industry as a result of many years of comprehensive research are not only high-chromium martensitic steels, such as: P91, P92, E911, or P122(A), but also low-alloy bainitic T23 and T24 steels. High properties of the new-found steels were obtained thanks to the optimization of their chemical composition and microstructure [1-4].

Applying super- or ultrasuperparameters in power units required the introduction of not only new grades of steels or super alloys but also new grades of cast steels. Previously used steel casts (turbine bodies and cylinders, T-pipes, valve chambers, etc.) made of low-alloy $\mathrm{Cr}-\mathrm{Mo}$ or $\mathrm{Cr}-\mathrm{Mo}-\mathrm{V}$ cast steels fail to meet those requirements.

Steel castings are of great significance for the highly-loaded elements of a turbine, i.e. valve bodies, valve chambers, outer and inner casings, etc. In the case of usage at the temperatures up to $600^{\circ} \mathrm{C}$ it is necessary to apply the improved steel castings of $9 \ldots 12 \%$ $\mathrm{Cr}$ content. Mechanical properties and high resistance to thermal shock of the cast steels with high-tempered martensitic microstructures is what makes them suitable for usage.

Corresponding author: G. GOLAŃSKI, e-mail: grisza@wip.pcz.czest.pl 
High requirements put for the new-found grades of high-chromium cast steels included:

- a $100000 \mathrm{~h}$ creep strength of $100 \mathrm{MPa}$ at $600^{\circ} \mathrm{C}$;

- good cast ability and weld ability;

- through-hardening capability up to about $500 \mathrm{~mm}$ wall thickness;

- properties such as fracture toughness, low-cycle fatigue strength and long-term toughness corresponding at least to those of the low-alloy ferritic cast steels currently used up to $565^{\circ} \mathrm{C}[5,6]$.

The above requirements were met by the new grades of steels with their chemical composition similar to that of high-chromium steels. These grades include steel casts such as: GX12CrMoVNbN9-1, GX12CrMoWVNbN10-1-1, or GX23CrMoV12-1. The fact that there are relatively few literature sources [5-8] concerning martensitic cast steels assigned for operation under supercritical parameters has encouraged the author to study the subject matter of those materials. The aim of the research carried out was to determine the influence of multistage heat treatment on the microstructure and mechanical properties of GX12CrMoVNbN9-1(GP91) cast steel.

Methodology of research. Microstructural research was performed by means of an optic microscope - Axiovert 25 on the conventionally prepared metallographic specimens etched with ferrous chloride and by means of JOEL JEM-3010 high-resolution transmission electron microscope using thin foils. Identification of precipitates was made by means of thin foils and extraction carbon replicas. The tests were carried out on samples in the as-cast state (as-received condition) and after heat treatment at the assumed parameters of temperature and time. Mechanical properties were examined according to the currently obeyed standards. The static tension test (yield point (YP); tensile strength (TS); elongation (El); reduction of area (RA)) was made by means of the MTS-810 testing machine on test pieces with their initial gauge diameter of $d_{0}=8 \mathrm{~mm}$. Measurement of hardness (HV30) was done by using the Vickers method with the load of $30 \mathrm{~kg}(294.2 \mathrm{~N})$ by means of the Future-Tech FV-700 testing machine. Tests of impact energy (KV) were carried out on non-standard test pieces of the Charpy "V" type. In the case of the static tensile test and the impact energy measurement, the presented results are the mean value of three tests, while the hardness value is the mean value of five measurements.

Material for research. The material under investigation was a cast steel of the following chemical composition: $0.12 \mathrm{C} ; 0.49 \mathrm{Mn} ; 0.31 \mathrm{Si}$; $0.014 \mathrm{P} ; 0.004 \mathrm{~S} ; 8.22 \mathrm{Cr}$; $0.90 \mathrm{Mo} ; 0.12 \mathrm{~V} ; 0.07 \mathrm{Nb} ; 0.04 \mathrm{~N}$. The chemical composition of the examined alloy corresponded to that of GX12CrMoVNbN9-1 (GP91) cast steel.

High volume fraction of chromium, the addition of molybdenum (ca. 1\%) and the microadditions of vanadium and niobium provide a good hardening capacity of the examined cast steel. Sections being around $50 \mathrm{~mm}$ thick are hardened in the air, while the casts of larger sections require faster cooling from the austenitizing temperature; in modern steel foundries the polymers are used for cooling, however in the traditional ones the coolant is still oil $[9,10]$.

In order to provide maximum similarity between the macrostructure of samples and the macrostructure of casts, samples for tests were taken from the equiaxed zone.

Heat treatment of GX12CrMoVNbN9-1 (GP91) cast steel. The heat treatment parameters of temperature and time for the examined GP91 cast steel were taken from works [6-8]. The applied parameters of heat treatment correspond to the treatment of casts of about dozen tons under industrial conditions. The GP91 cast steel was heattreated in three variants which differed in the number of treatment operations, temperatures and holding times. The heat treatment parameters of temperature and time for the examined GP91 cast steel are presented in Table 1.

Last steps at 730 (heat treatment № 1 and № 2) and $750^{\circ} \mathrm{C}$ (heat treatment № 3) were given to simulate a Post Weld Heat Treatment (PWHT). 
Table 1. Heat treatment parameters of temperate and time for the GP91 cast steel

\begin{tabular}{|c|c|c|}
\hline $\begin{array}{c}\text { Heat } \\
\text { treatment }\end{array}$ & Heat treatment parameters of temperate and time for GP91 cast steel & Ref. \\
\hline № 1 & $\begin{array}{c}780^{\circ} \mathrm{C} / 8 \mathrm{~h} / \text { furnace }+1040^{\circ} \mathrm{C} / 12 \mathrm{~h} / \text { air }+730^{\circ} \mathrm{C} / 8 \mathrm{~h} / \text { air }+ \\
+730^{\circ} \mathrm{C} / 8 \mathrm{~h} / \text { furnace }\end{array}$ & {$[6]$} \\
\hline № 2 & $\begin{array}{c}1000^{\circ} \mathrm{C} / 15 \mathrm{~h} / \text { furnace }+1100^{\circ} \mathrm{C} / 12 \mathrm{~h} / \text { air }+730^{\circ} \mathrm{C} / 12 \mathrm{~h} / \text { air }+ \\
+730^{\circ} \mathrm{C} / 12 \mathrm{~h} / \text { furnace }\end{array}$ & {$[7]$} \\
\hline № 3 & $1040^{\circ} \mathrm{C} / 12 \mathrm{~h} /$ air $+760^{\circ} \mathrm{C} / 12 \mathrm{~h} /$ air $+750^{\circ} \mathrm{C} / 8 \mathrm{~h} /$ furnace & {$[8]$} \\
\hline
\end{tabular}

Structure and properties of GP91 cast steel in the as-received condition. High hardening capacity of the investigated cast steel and its coarse grain structure in the ascast state allowed us to obtain the microstructure of coarse grain martensite (Fig. 1). The microstructure of the cast steel in the as-cast condition was characterized by a lath structure of martensite with a large dislocation density and polygonal substructure (Fig. 1b). The width of martensite laths amounted to ca $0.30 \ldots 0.45 \mu \mathrm{m}$. In the structure on the lath boundaries, subgrain boundaries and inside laths the numerous precipitates of diverse morphology were observed (Fig. 1b; Fig. 2).
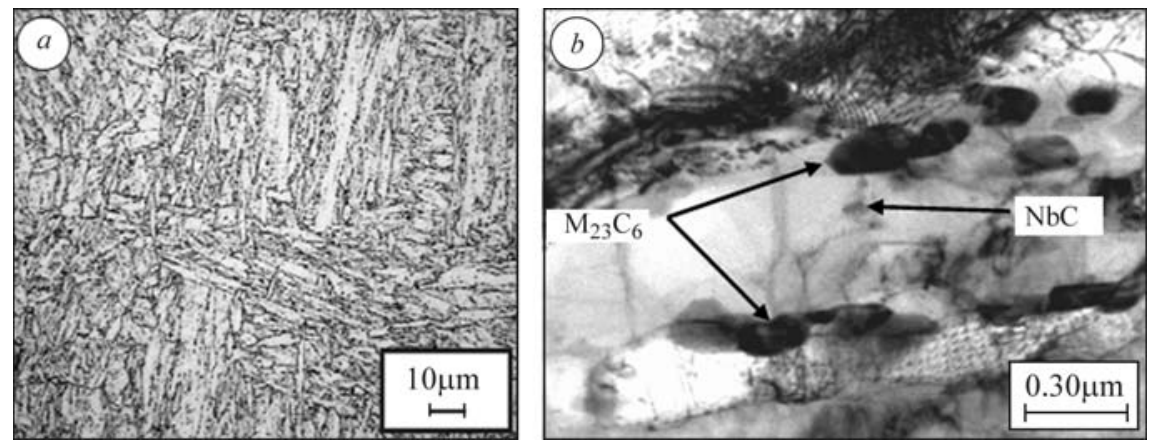

Fig. 1. Microstructure of the GP91 cast steel in the as-cast state: $a$-OM; $b-\mathrm{TEM}$, thin foil.

Performed identification of precipitates in GP91 cast steel by means of electron diffraction has revealed the presence of: large, about the size of $100 \ldots 350 \mathrm{~nm} \mathrm{M}{ }_{23} \mathrm{C}_{6}$ carbides precipitated mostly on former austenite grain boundaries, martensite laths boundaries and inside the grains; fine-dispersion spheroidal $\mathrm{NbC}$ carbides precipitated on dislocations inside martensite laths as well as on subgrain boundaries (Fig. 1b); precipitates of lamellar $\mathrm{M}_{3} \mathrm{C}$ carbides of $40 \ldots 100 \mathrm{~nm}$ forming the Widmannstätten pattern (Fig. 2).

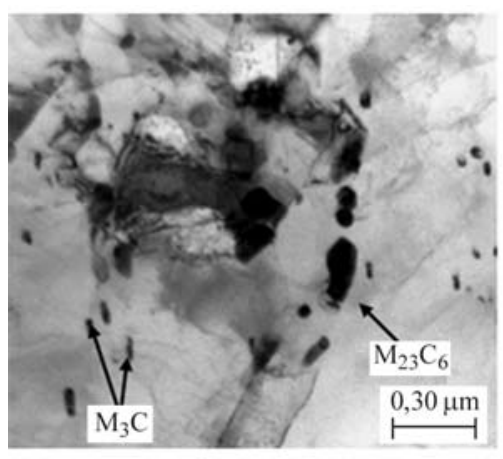

Fig. 2.

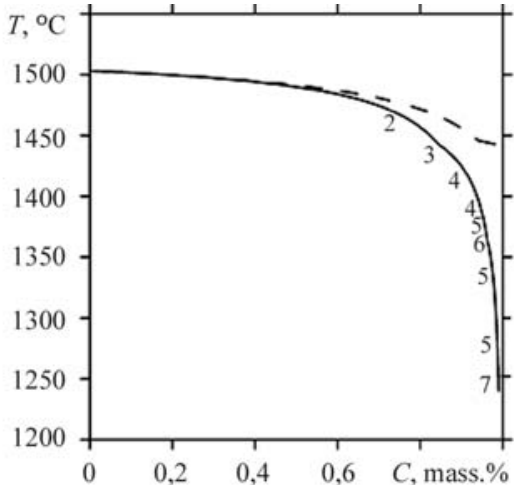

Fig. 3.

Fig. 2. Effects of self-tempering of martensite in GP91 cast steel in the as-cast state, TEM, thin foil.

Fig. 3. The course of solidification of the GP91 cast steel determined by means of the ThermoClac program. 1 - Liquid; 2 - Liquid BCC A2; 3 - Liquid BCC A2 FCC A1 № 1; 4 - Liquid FCC_A1 № 1; 5 - Liquid FCC_A1 № 1 FCC_A1 № 2; 6 - Liquid FCC_A1 № 2; 7 - Liquid FCC_A1 № 1 FCC_A1 № 2 M7C3. 
High temperature of the beginning phase of martensite transformation $\mathrm{M}_{\mathrm{s}}$, amounting to $386^{\circ} \mathrm{C}$ for the investigated cast steel, creates the possibility of carbon diffusion. This can lead to the effect of self-tempering of martensite as a result of $\mathrm{M}_{3} \mathrm{C}$ carbides precipitation in the microstructure (Fig. 2). A similar process of martensite self-tempering was also observed in high-chromium steels $[2,11]$. Carbides (carbonitrides) of niobium $\mathrm{NbC}$ are precipitated in the final phase of coagulation and they are an inhibiting factor for austenite grain growth during heat treatment, which significantly affects later the properties of the alloy $[12,13]$.

Obtained results are proved by the results of numerical simulation of solidification for the examined cast steel which were received by means of the ThermoClac program according to the Scheil-Gulliver model (Fig. 3).

Mechanical properties of GP91 cast steel in the as-received condition are presented in Table 2. Properties of the investigated cast steel were higher than the required minimum. (Demands put for the examined cast steel were taken from [14]).

The TS and YS determined for GP91 cast steel in the as-cast state were higher than the demanded minimum by 7 and $2 \%$ respectively. Similarly, plastic properties i.e. impact strength, was more than three times as high as the minimum and $\mathrm{El}$ was by ca 33\% higher than the minimum. Hardness of the examined cast steel in the as-cast state amounted to 232 HV30, whilst the RA percentage $-58 \%$ (Table 2). Required mechanical properties in the as-received condition is what GP91 cast steel owes to the lath microstructure of low-carbon martensite (Fig. 1). Coarse grain cast structure of GP91 cast steel, unfavorable in terms of properties, is subject to refinement with martensite laths. This leads to an increase in strengthening with grain boundaries which is favorable not only for plastic properties but also for strength properties. According to data provided by study [13] strengthening with grain boundaries in the case of martensitic structure is dependent on the width of martensite laths and amounts to $239.4 \mathrm{MPa}$ for the width of $0.36 \mu \mathrm{m}$ (similar to the investigated cast steel).

Table 2. Mechanical properties of the GP91 cast steel in the as-received condition

\begin{tabular}{|c|c|c|c|c|c|c|}
\hline & TS & YS & El & RA & \multirow{2}{*}{$\begin{array}{c}\mathrm{KV}, \\
\mathrm{J}\end{array}$} & \multirow{2}{*}{ HV30 } \\
\hline & \multicolumn{2}{|c|}{$\mathrm{MPa}$} & \multicolumn{2}{|c|}{$\%$} & & \\
\hline in the as-received condition & 644 & 506 & 20 & 58 & 94 & 232 \\
\hline requirements of the DIN [14] & $600 \ldots 750$ & $\min .500$ & $\min .15$ & - & $\min .30$ & - \\
\hline
\end{tabular}

Microstructure and properties of GP91 cast steel after heat treatment. Heat treatment of GP91 cast steel contributed to obtaining a fine grain microstructure of high-tempered martensite regardless of the assumed parameters of temperature and time (Table 1). Examples of the GP91 cast steel microstructures after heat treatment are shown in Fig. 4. Heating the examined cast steel to the temperature of austenitizing caused the reduction of the initial austenite grain which in consequence contributed to the obtainment of a fine grain martensitic microstructure. In the case of sample № 2 (see Table 1) as a result of twice heating above the temperature $A_{c 1}\left(A_{c 3}\right)$ there was a greater refinement of microstructure observed in comparison with the cast steels heated only once (Fig. 1 $a, c$ ). Grain size reduction acts favorably on mechanical properties of the cast steel in two opposite directions - at the same time it raises the YS and impact energy and decreases the nil ductility transition (NDT) temperature. High temperature and long times of holding at the temperature of tempering and annealing contributed to the precipitation of numerous carbides of diverse size. Carbide precipitates were observed on the former austenite grains as well as on the boundaries of martensite laths and inside martensite grains (Fig. $4 b, d$ ). Long-term holding at the time of tempering and stress relief annealing after PWHT, as indicated in practice [2,13, 15], contributes to obtaining a very stable microstructure during casts service. 

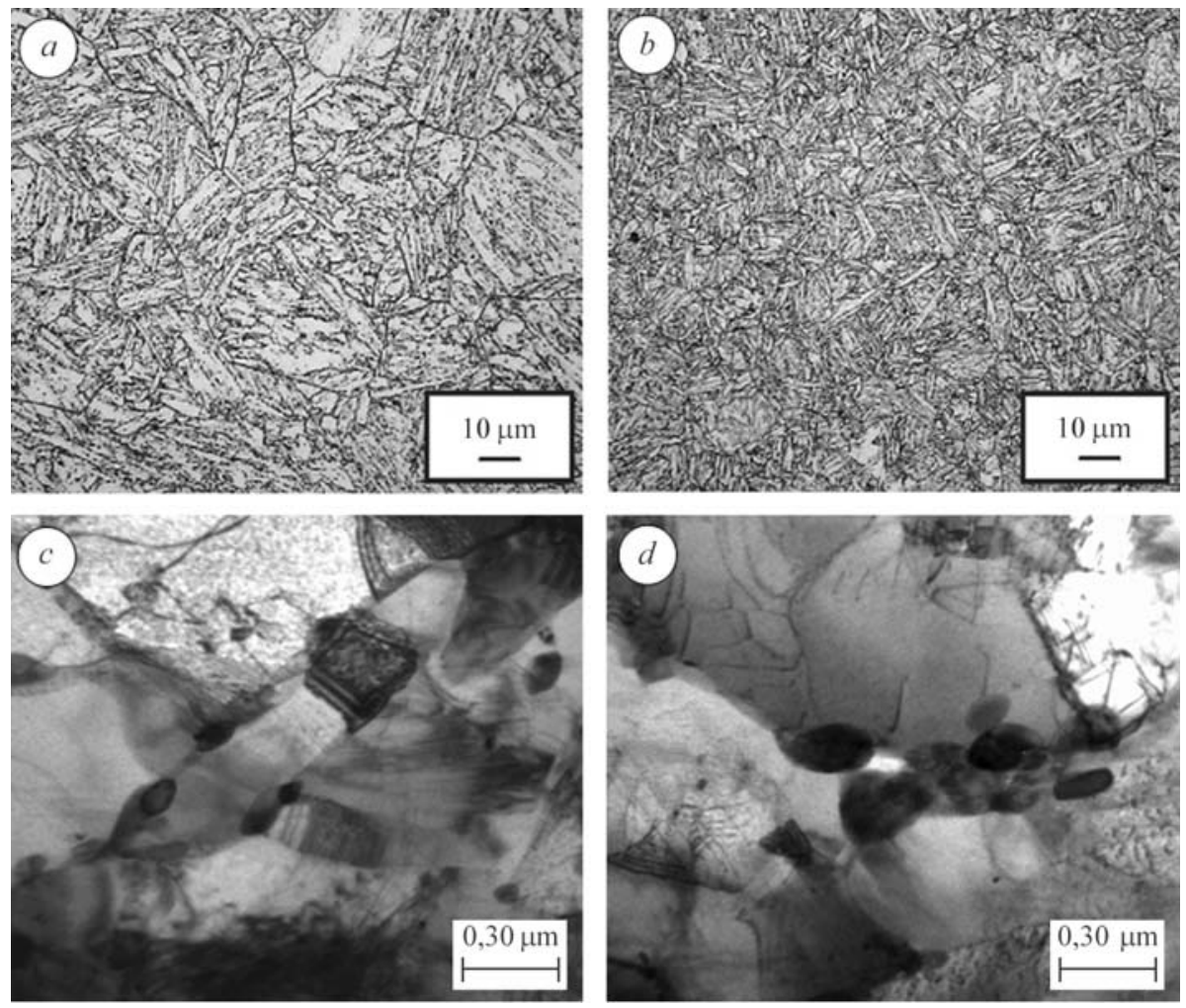

Fig. 4. Microstructure of the GP91 cast steel after heat treatment: $a, b$ - treatment № 1; $c, d$ - treatment № 2. $a, c$ - OM; $b, d$ - TEM, thin foil.

Microstructures of GP91 cast steel after different heat treatment variants were similar and characterized by a lath substructure of martensite with large dislocation density and polygonal ferrite grains. The dislocation boundaries appeared between martensite laths and between subgrains. Performed identifications of precipitates in cast steels after heat treatment revealed only the occurrence of $\mathrm{M}_{23} \mathrm{C}_{6}$ and $\mathrm{MX}$ carbides in the microstructure. Numerous $\mathrm{M}_{23} \mathrm{C}_{6}$ carbides were mostly located on the boundaries of former austenite grain and the boundaries of subgrains/laths of martensite. Only some sparse carbides of this type were observed also inside ferrite subgrains. A size of the precipitated $\mathrm{M}_{23} \mathrm{C}_{6}$ carbides was diverse and ranged from ca. $60 \mathrm{~nm}$ to more than $210 \mathrm{~nm}$. Fine dispersive precipitates of the MX type, i.e. NbC carbides as well as VX nitrides (carbonitrides) were noticed on the dislocations inside subgrains and on subgrain boundaries. Single MX precipitates were also revealed on the boundaries of the initial austenite grains. Revealed in the microstructure $\mathrm{M}_{23} \mathrm{C}_{6}$ carbides, which were precipitated on the boundaries of sunbgrains/laths of martensite, stabilize the subgrain microstructure of martensite inhibiting the movement of dislocation boundaries, while fine dispersive precipitates of MX ensure the high creep resistance inhibiting the movement of dislocations.

The results of research on the mechanical properties of GP91 cast steel after heat treatment are presented in Fig. 5.

The conducted research on the mechanical properties of GP91 cast steel after different heat treatment variants (Table 1) has proved that:

- a long-term holding at the temperatures of tempering and annealing contributes to the YS decrease. It is lower than the required minimum value by around $2 . . .5 \%$ (depending on the heat treatment mode). Tempering and annealing of the examined cast steel at the temperatures above $700^{\circ} \mathrm{C}$ for many hours leads to a decrease in strengthe- 
ning: in the dislocation - strengthening as a result of the process of recovery and recrystallization of the matrix; in the solid solution - strengthening by alloying elements as a result of diffusion of atoms of the carbide forming elements to carbides; and in the precipitation strengthening - as a result of the process of precipitates coagulation, mainly carbides of the $\mathrm{M}_{23} \mathrm{C}_{6}$ type. A decrease in the dislocation density, fall of concentration of alloy elements in the matrix and an increase in the size of precipitates leads in consequence to the YS reduction. According to the literature data [7] extending the time of tempering at the temperature of $730^{\circ} \mathrm{C}$ from five to $25 \mathrm{~h}$ contributes to the reduction of YS and TS of high-chromium cast steel by around 12 and 4\%, respectively. Despite the above, tempering (or/and annealing) of the steel casts for many hours at the temperature above $700^{\circ} \mathrm{C}$ is necessary for obtaining a thermodynamically stable microstructure;

- austenite grain size reduction as a result of austenitizing and fall of the matrix strengthening of the investigated cast steel contributed to the increase in plastic properties, mostly impact strength (Fig. 5);

- TS of the GP91 cast steel in the as-cast state as well as after heat treatment was similar and higher than the standard requirements;

- hardness of GP91 cast steel after heat treatment was higher than 200 HV30, which indicates high stability of the examined alloy microstructure.
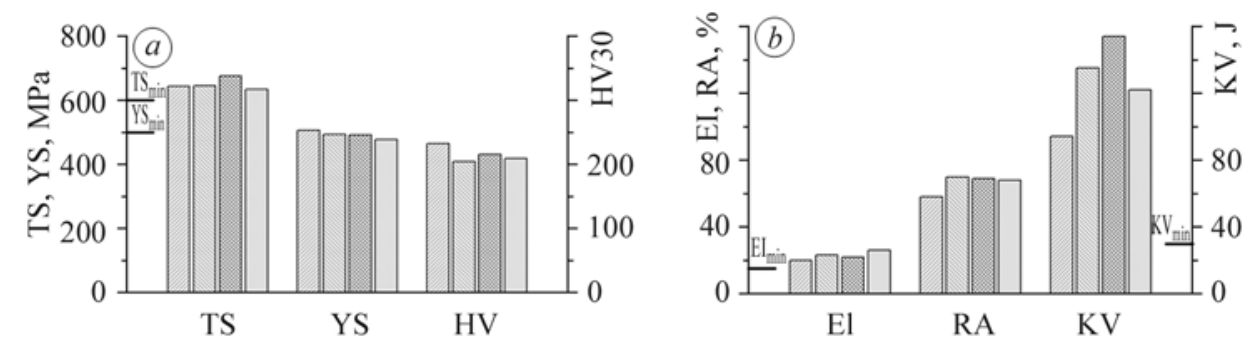

Fig. 5. Comparison of properties: $a$-strength properties; $b$ - plastic properties of the GP91 cast steel in the as-cast state and after heat treatment.

$\square$ - as received condition; $\square-$ № 1; $\square-$ № 2; $\square-$ № 3 .

\section{CONCLUSIONS}

The GP91 cast steel with its coarse grain structure in the as-cast state is characterized by high mechanical properties which result from the lath microstructure of lowcarbon martensite. High properties of GP91 cast steel in the as-cast state indicate a dominant role of the dislocation boundaries between martensite laths in the strengthening mechanism, and the insignificant role of broad-angle boundaries of the former austenite grain. The heat treatment of GP91 cast steel most of all contributes to the increase in plastic properties, impact strength in particular. Strength properties after heat treatment, due to long times of holding at the temperatures above $700^{\circ} \mathrm{C}$, maintain on the level of properties of the cast steel in the as-cast state. The values of YS of GP91 cast steel after heat treatment are insignificantly lower than the required minimum, which is connected with a decrease in matrix strengthening, as a result of long tempering and annealing. However, long times of tempering at the temperatures above $700^{\circ} \mathrm{C}$ favour getting a microstructure with possibly the highest thermodynamic stability.

РЕЗЮМЕ. Подано результати досліджень впливу різного виду багатоетапної термообробки на мікроструктуру і властивості високохромової мартенситної литої сталі GX12CrMoVNbN9-1 (GP91). Для досліджень взято зразки, отримані з пробного злитка. Термообробку литої сталі GP91 здійснювали в температурно-часових параметрах, характерних для обробки багатотонного лиття сталі. Дослідження показали, що в литому стані сталь GP91 має грубозернисту мікроструктуру пластинчастого мартенситу із вмістом карбідів типу $\mathrm{M}_{23} \mathrm{C}_{6}, \mathrm{M}_{3} \mathrm{C}$ i $\mathrm{NbC}$, яка відповідає механічним властивостям за стандартом. За допомогою термообробки литої сталі GP91 отримано дрібнозернисту мікроструктуру ви- 
соковідпущеного пластинчастого мартенситу з чисельними вкрапленнями типу М23С6 i MX різного розміру. Структура литої сталі GP91 після термообробки одержала високі пластичні характеристики, переважно пружності, з властивостями міцності (межі пластичності) наближені до необхідного мінімуму.

РЕЗЮМЕ. Представлено результаты исследований влияния различного вида многоэтапной термообработки на микроструктуру и свойства высокохромовой мартенситной литой стали GX12CrMoVNbN9-1 (GP91). Для исследований взято образцы, получённые из пробного слитка. Термообработку литой стали GP91 осуществляли в температурновременных параметрах, соответствующих обработке многотонного литья стали. Исследования показали, что в литом состоянии сталь GP91 имеет крупнозернистую микроструктуру пластинчатого мартенсита с содержанием карбидов типа $\mathrm{M}_{23} \mathrm{C}_{6}, \mathrm{M}_{3} \mathrm{C}$ и $\mathrm{NbC}$, которая соответствует требуемым механическим свойствам по стандарту. С помощью термообработки литой стали GP91 получено мелкозернистую микроструктуру высокоотпущенного пластинчатого мартенсита с многочисленными вкраплениями типа $\mathrm{M}_{23} \mathrm{C}_{6}$ и $\mathrm{MX}$ различного размера. Структура литой стали GP91 после термообработки получила высокие пластические характеристики, преимущественно упругости, со свойствами прочности (границы пластичности) приближенные к требуемому минимуму.

Acknowledgements. Scientific work funded by the Ministry of Education and Science for 2010-2012 as a research project No. N N507 510 838. Author would like to extend his sincere thanks to Alstom Power sp. $z$ o.o. in Elblag (Metallurgic Plant) for providing the material for research.

1. Ferritic and austenitic grade steel for new generation of steam power plants / S. Caminada, L. Cipolla, G. Cumino, et al. // $5^{\text {th }}$ Int. Conf. "Advances in Materials Technology for Fossil Power Plants". - Florida: Marco Island, 2007. - P. 564-581.

2. Zielińska-Lipiec A. The analysis of a microstructural stability of modified martensitic $9 \% \mathrm{Cr}$ steels during annealing and creep deformation // AGH Publ. - Cracow, 2005. - ISSN 0867-6631.

3. Golański G. and Stachura S. Characterization of new low alloy steels for power plant // Hutnik - wiadomości hutnicze. - 2009. - 9. - P. 679-683.

4. Chmielniak T. Evolution directions of main machines and equipment for new solutions and ideas of power blocks / Ed.: A. Hernas // Materials and Technology for Construction of Supercritical Boilers and Waste Plants. - Katowice: SITPH Publ. 2009. - P. 12-26.

5. Evolution of microstructure and properties of $10 \% \mathrm{Cr}$ steel castings / H. K. Mayer, $\mathrm{H}$. Cerjak, P. Hofer, E. Letofsky and F. Schuster // Microstructural development and stability in high chromium ferritic power plant steels, Eds.: A. Strang and D. J. Gooch. - London: The Institute of Materials, 1997. - P. 105-122.

6. Effect of thermal ageing on mechanical properties and microstructure of a standard G-X12CrMoVWNbN1011 grade of cast steel for turbine casing / S. C. Bose, K. Singh, A. K. Ray, and R. N Ghosh // Mater. Scie. Engng. A. - 2008. - 476. - P. 257-266.

7. Hanus $R$. Advanced $9-12 \% \mathrm{Cr}$ cast steel grades, research - foundry process development quality - experience $/ / 4^{\text {th }}$ Int. Conf. "Advances in Materials Technology for Fossil Power Plants. - South Carolina: Hilton Head Island, 2004. - P. 638-651.

8. Microstructural evolution of the martensitic cast steel GX12CrMoVNbN9-1 during longterm annealing and creep / S. Straub, P. Polcik, W. Besigk, et al. // Steel Research. - 1995. -66, № 9. - P. 402-408.

9. Theoretical investigation and experimental application of aqueous polymer solution for quenching products of low-alloy cast steel / A. Bakalarski, A. Nowarski, J. Sus, and K. Wyszyński // Przeglad Odlewnictwa. - 2001. - 51, № 2. - P. 61-64.

10. Eukowski J. Modern installations for quenching with the application of aqueous polymer solutions // Ibid. - 2001. - 51, № 2. - P. 57-60.

11. Janovec J., Svoboda M., and Blach J. Evolution of secondary phases $12 \% \mathrm{Cr}$ steel during quenching and tempering // Mater. Scie. Engng. A. - 1998. - 249. - P. 184-189.

12. Hannerz N. E., Lindborg U., and Lehtinen B. Brittleness in a cast steel caused by $\mathrm{NbC}$ precipitation // JISI. - 1968. - P. 68-73.

13. Qiang Li Modeling the microstructure - mechanical property relationship for a $12 \mathrm{Cr}-2 \mathrm{~W}-\mathrm{V}$ -Mo-Ni power plant steel // Mater. Scie. Engng. A. - 2003. - 361. - P. 385-391.

14. ECCC Data Sheet. - 2005. - P. 51-52.

15. Microstructural characterization of modern martensitic steels / K. Maile, F. Kauffmann, A. Klenak, E. Roos, S. Straub, and K. H. Mayer // $5^{\text {th }}$ Int. Conf. "Advances in Materials Technology for Fossil Power Plants. - Florida: Marco Island, 2007. - P. 675-688.

Received 03.03.2011 